\title{
Financial Development, Government R\&D Subsidies and Green Innovation
}

\author{
Shuying Wang ${ }^{1}$, Bobo $\mathrm{Li}^{1}$ and Shuijuan Zhang ${ }^{1}$ \\ ${ }^{1}$ School of Management Engineering, Zhengzhou University, Zhengzhou 450001, China \\ Email: wangshuying@zzu.edu.cn,1796149399@qq.com,1563536373@qq.com
}

\begin{abstract}
In the low carbon economic era, green innovation has become an important basis for an enterprise to obtain and maintain a sustained competitive advantage.In paper, explores the path of green innovation using the panel data of 30 regions in China from 2008 to 2014.It finds that financial development has heterogeneity and different dimensions of financial development have different effects on green innovation of enterprises. That is, financial development structure has a negative impact on enterprise green innovation, and financial development efficiency has a positive impact on green innovation. Howere, the impact between financial development scale and green innovation is not significant. In addition, the study also finds that government $R \& D$ subsidies has no significantly effect on green innovation. Finally, this paper aims to provide the government and enterprises some theoretical and practical guidance to carry out policy-making of green innovation.
\end{abstract}

Keywords. Green innovation, financial development structure, financial development efficiency, financial development scale, government R\&D subsidies.

\section{Introduction}

With the increasingly serious environmental problems, green sustainable development has become a common choice of countries around the world. In this context, green innovation has caused a great concern as an important way to alleviate environmental problems. From the national level, green innovation can produce positive externalities through the spillover of knowledge and technology, which is helpful to improve the efficiency of resource utilization and speed up the transformation of the national economic development mode, becoming the inevitable choice for the country to obtain and maintain the core competitive advantage. From the enterprise level, green innovation has a certain impact on the innovation activities of the whole enterprise (Aghion, 2012) [1],which helps to promote enterprises in production, operation and management changes and has an important impct on enhancing enterprise competition advantages and performance. In terms of the development of green innovation theory and practice in China, the research of green innovation in our country is still in the initial stage. Therefore, it is necessary to learn and utilize the green innovation system, management, technology and service in developed countries to provide important support for green innovation of Chinese enterprises.

Financial development and government R\&D subsidies have important effects on the innovation activities of enterprises, which provide dynamic support for enterprise innovation through market stimulation and government 
regulation. Financial development, as a kind of market pull, can effectively integrate investment information, mobilize savings, improve resource allocation efficiency, improve enterprise supervision and timely disperse risk, which plays an important role in innovation activities (Levine, 1997) [2]. Relative to financial development, as a kind of government regulation and control, government R\&D subsidies can mitigate the possible "market failure" (Hall, 2000) [3] and plays a crucial role in the innovation activities of enterprises.

The vast majority of past research has examined the effects among financial development, the government R\&D subsidies on the general technology innovation, and provided substantial material and theoretical reference for the research of this paper, but there are still some limitations. First, most of the past studies ignored the heterogeneity of financial development. Thus, this article divids financial development into financial development scales, financial development structure and financial development efficiency, and respectively explores the three dimensions' impact on green innovation. Second, the existing research about the effects of government R\&D subsidies on green innovation has not yet reached a consensus. Third, few studies integrate financial development, government R\&D subsidies, and green innovation into the same research framework to systematically analyze the role of variables.

Based on the above analysis, using panel data of 30 regions in China, this article constructs the theoretical framework to further explore the impact of financial development and government R\&D subsidies on green innovation, hoping to further expand green innovation theory and provide useful reference for enterprises to carry out green innovation activities.

\section{Theory and hypotheses}

\subsection{Financial development and green innovation}

Green innovation is a high-input process with a high degree of uncertainty and risk. In contrast to other activities, companies are often faced with financial constraints when undertaking green innovations (Hall \& Lerner, 2010) [4].The financial system takes on the foremost financial activities and is an important means for the effective allocation of resources in the process of enterprise innovation. On the one hand, financial development can mitigate the financial constraints and improve the efficiency of resource allocation. Enterprises need to invest lots of R\&D funds to green innovation. Companies can only seek help through external financing when a shortage of funds within the enterprise. Financial intermediaries and financial markets through various types of financing mechanisms to integrate social idle funds to meet the financing needs of green innovation. A well-developed financial development system not only provides sufficient external financing for corporate innovation to mitigate financial constraints (Ben \& Goaied, 2008) [5], but also helps investors to obtain information on enterprise investment and financing decision-making, reduce information asymmetry, improve the allocation of financial resources efficiency (Habia, 2008) [6].On the other hand, financial development can reduce the uncertainty and risk of green innovation investment. Due to the high risk of green innovation, many enterprises and individuals tend to put capital into low risk areas, which hinders the development of green innovation. According to Levine (1997) [2], financial development has the function of dispersing risk, which can reduce the uncertainty and risk in the process of green innovation to a certain extent.

Sun and Wang (2013) [7] studied the relationship between financial development and technological innovation, showing that financial development has a catalytic role in technological innovation.Bo et al (2013) [8]suggested that financial development scale, financial development efficiency and financial development structure are important factors impacting technological innovation capacity. Li et al (2013) [9] believed that the financial development scale has a significant positive effect on R\&D investment. He et al (2011) [10] considerded that the strengthening of financial market development, expansion of direct financing channels and the scale is more conducive to enterprise independent innovation. Zhang (2012) [11] found that financial development scale and efficiency has significant $R \& D$ innovation effect. Based on the above analysis, the following hypotheses are proposed:

H1: There is a positive correlation between financial development scale and green innovation. 
$\mathrm{H} 2$ : There is a positive correlation between financial development efficiency and green innovation.

The financial structure depicts the relative importance of the stock market in comparison with the banking intermediaries. According to the current development, China's financial development structure is basically a bank-led financial structure (He \& Chang,2010 [12]Sun\&Wang,2013 [7]).Roger(2011) [13] and Ferreira (2012) [14] argue that banks would tend to deny loan support for high-risk, high-yield innovative projects in order to achieve soundness in their operations, which would make it difficult for banks to obtain credit for these projects. Therefore, it can be found that the financial system dominated by banks is not conducive to the innovation activities. Sun and Zhu (2008) [15],He and Chang(2010) [12]also believed that bank-led financial structure seriously restrictes the independent innovation of enterprises. Based on the above analysis, the hypothese is proposed:

H3: There is a negative correlation between financial development structure and green innovation.

\subsection{Government R\&D subsidies and green innovation}

Green innovation of enterprises may face the high risk of R\&D investment and external spillover. If the government does not carry out R\&D subsidies, the enthusiasm of enterprises R\&D investment can be dampened. From the point of risk control and $R \& D$ costs, government $R \& D$ subsidies can stimulate the enthusiasm of enterprises to innovate and expand their R\&D investment (Yager \& Schmidt, 1997) [16].In addition, government R\&D subsidies has significant leverage on R\&D innovation of enterprises, which can largely compensate for the "market failure" of green innovation. The existing literatures discussed the impact of government R\&D subsidies on innovation of enterprise. Spencer and Brander (1985) [17] found that government R\&D subsidies has similar utility as export subsidies, which can stimulate innovation activities and affect the equilibrium behavior of R\&D competition. Hewitt and Roper (2010) [18]conducted a study of Ireland and Northern Ireland data for 1994-2002 and found that government subsidies has apositive impact on the proportion of enterprise $R \& D$ activities and product improvement innovation activities. Bai (2011) [19] conduted an empirical analysis, regarding that government R\&D subsidies significantly improves the efficiency of R\&D innovation. Ding and Zhu (2016) [20]analyzed the impact of government R\&D subsidies on the performance of technological innovation. The results shown that government $R \& D$ subsidies has positively influenced the performance of technological innovation in a high-tech industry. In sum, government R\&D subsidies can help to compensate for the lack of investment in innovation, to solve the problem of knowledge spillovers, and to reduce the risk of $R \& D$, thus stimulating the enterprise green innovation. Based on the above analysis, the hypothese is proposed:

H4: There is a positive correlation between government R\&D subsidies and green innovation.

\section{Research design}

\subsection{Variable selection}

\subsubsection{Dependent variable}

At present, the measurement of green innovation (gi) has not yet reached a consensus in China. Li et al(2013) [21] adopted the new product unit energy consumption, that is, the ratio of energy consumption to new product output. Wang and Guo (2015) [22] used the ratio of new product sales revenue to energy consumption. Taking into account the availability of data, this paper uses the indicator given by Wang and Guo (2015) [22] to measure green innovation.

\subsubsection{Explanatory variables}


The explanatory variables of this paper are financial development scale (fd1), financial development structure (fd2), financial development efficiency (fd3) and government R\&D subsidies (s). According to the research of Bai et al. (2013) [8], Chang and Ju (2015)[23], the financial development scale is measured by the ratio of the sum of financial institutions' deposits and loans balance to GDP in each region; the financial development structure is measured by the ratio of stock's total market value to financial institutions' loans balance in each region; the financial development efficiency is measured by the ratio of financial institutions' deposits balance to loans balance in each region. According to the research of Wang (2010) [24], government R\&D subsidies (s) is measured by the funds from the government to raise funds for enterprise science and technology.

\subsubsection{Control variables}

The control variables are human capital (hum) and economic development (ed).Human capital (hum) is the main body of enterprise innovation activities and reflects the enterprise's digestion and absorption abilities of new knowledge. This article uses the average schooling years of labor force to measure human capital (Barro,2001) [25].The formula is: the average schooling years of labor force $=6 a_{1}+9 a_{2}+12 a_{3}+16 a_{4}$, which $a_{1}, a_{2}, a_{3}, a_{4}$ respectively represent the proportion of primary school, junior high school, high school ,college education and above residents to the population aged 6 and over in the provinces. The economic development can provide a strong support for enterprises' innovation. This article uses per capita GDP to measure the economic development in in each region.

\subsection{Sample data and sources}

Considering the availability and validity of the data,this paper chooses the industrial enterprises above designated size in 30 provinces of China as the research object, and takes the panel data from 2008 to 2014 as the sample(due to the lack of data in the Tibet Autonomous Region is serious, this article removes the Tibet Autonomous Region). The data are from China Statistical Yearbook, China Statistical Yearbook of Science and Technology, China Statistical Yearbook on Population and Employment, Statistical Yearbook of Science and Technology Activities of Chinese Industrial Enterprises and China Financial Yearbook.The data is analyzed using Stata14.0.

\subsection{Estimation Method}

Based on the above analysis, in order to better investigate financial development, government R\&D subsidies on the impact of green innovation, this paper establishs the panel model:

$$
\begin{aligned}
g i_{i t} & =\alpha_{0}+\alpha_{1} f d 1_{i t}+\alpha_{2} f d 2_{i t} \\
& +\alpha_{3} f d 3_{i t}+\alpha_{4} s_{i t}+\alpha_{5} h u m_{i t} \\
& +\alpha_{6} e d_{i t}+\varepsilon_{i t}
\end{aligned}
$$

$g i_{i t}, f d 1_{i t}, f d 2_{i t}, f d 3_{i t}, s_{i t}, h u m_{i t}, e d_{i t}$ respectively represent green innovation ,financial development scale, financial development structure, financial development efficiency, government R\&D subsidies, human capital and economic development of region $\mathrm{i}$ in the period t. ${ }^{{ }_{i t}}$ represents the error term of region $\mathrm{i}$ in the period t. In order to eliminate the impact of heteroskedasticity, government R\&D subsidies, human capital and economic development are all natural logarithm. 


\section{Empirical snalysis}

\subsection{Descriptive statistical analysis}

Descriptive statistics are shown in Table 1. Means, standard deviations, maximum and minimum values are summarized for all variables. As shown in Table 1, firstly, in terms of the average 21.65 and the standard deviation 53.74 ,the paper finds that green innovation has great regional differences. Secondly, from the level of financial development, the financial development scale, the financial development structure and the financial development efficiency are obvious regional differences. It implies that China 's financial development is unbalanced. The mean value of the financial development structure is 0.43 , which shows that China's financial structure is a banking-oriented financial structure in general (Sun \& Wang (2013)[7],He \& Chang(2010)[12]).

Table 1. Descriptive statistics.

\begin{tabular}{ccccc}
\hline $\begin{array}{c}\text { Variable } \\
\text { s }\end{array}$ & Mean & $\begin{array}{c}\text { Std. } \\
\text { dev. }\end{array}$ & Min & Max \\
\hline gi & 21.65 & 53.74 & 0.67 & 466.03 \\
fd1 & 2.92 & 2.19 & 0.90 & 28.35 \\
fd2 & 0.43 & 0.62 & 0.02 & 4.56 \\
fd3 & 1.77 & 3.68 & 0.16 & 47.34 \\
s & 10.75 & 1.31 & 5.09 & 12.87 \\
hum & 9.16 & 5.97 & 5.77 & 90.93 \\
ed & 9.07 & 0.23 & 8.66 & 11.42 \\
\hline
\end{tabular}

\subsection{Panel data regression analysis}

\subsubsection{Unit root test}

Before the panel regression, this paper carries out the stationarity test to examine the smoothness of the data for the purpose of preventing false regression or pseudo-regression. In this paper, ADF-Fisher test method is used. The test results show that the p-values of the ADF-Fisher test are less than 0.01 , rejecting the null hypothesis containing unit roots, indicating that each sequence is stationary and eliminates the existence of spurious or pseudo-regressions.

\subsubsection{Panel model selection}

Before the regression, it is necessary to test the form of the model to avoid the deviation caused by improper model setting in the regression process. In this paper, the Hausman test is used to examine the model. The Hausman test has a p-value of 0.006 , which indicates that the null hypothesis is rejected at the $1 \%$ level, so the fixed effect model is chosen.

\subsubsection{Regression results and analysis}

Based on the above analysis, this paper selected the fixed effect model to regress the model, the regression results are shown in Table 2.From the regression results in Table 2, the regression coefficient of financial development efficiency is 4.84 , and through the $1 \%$ significance test. It shows that the financial development efficiency is positively related to the green innovation of enterprises, that is, the financial development efficiency has significantly promoted the enterprise green innovation activities. This conclusion is similar to the finding of Ran et 
al (2013) [26] and $\mathrm{H} 2$ is verified. The regression coefficient of the financial development structure is -49.26 , and the $1 \%$ significance test is adopted. It shows that Chinese.

Table 2. Panel data regression results.

\begin{tabular}{ccccc}
\hline gi & Coef. & $\begin{array}{c}\text { Std. } \\
\text { Err. }\end{array}$ & $\mathrm{t}$ & $\mathrm{P}>|\mathrm{t}|$ \\
\hline $\mathrm{fd} 1$ & -0.13 & 1.19 & -0.11 & 0.91 \\
$\mathrm{fd} 2$ & -49.26 & 10.25 & -4.81 & $0.00^{* * *}$ \\
$\mathrm{fd} 3$ & 4.84 & 1.19 & 4.07 & $0.00^{* * *}$ \\
$\mathrm{~s}$ & -3.91 & 4.83 & -0.81 & 0.42 \\
$\mathrm{hum}$ & 0.57 & 0.95 & 0.60 & 0.55 \\
ed & -15.24 & 25.90 & -0.59 & 0.56 \\
\hline
\end{tabular}

Note: $* * * * *, *$ represent the $1 \%, 5 \%, 10 \%$ confidence level was significantly.

Banking-led financial structure has a significant hindrance to green innovation and is not conducive to the development of green innovation. H3 has been supported. This finding is consistent with the conclusions of Kang and Zhang (2008) [27], He and Chang (2010) [12],Sun and Wang (2013) [7].

From the regression results, the regression coefficient of financial development scale is negative, but not significant (Coef $=-0.13, \mathrm{p}=0.91$ ), which means that $\mathrm{H} 1$ has not passed the test. The possible causes of this result are the following. First, it may be because the scale of financial development indicators have yet to be improved or data sources are inadequate, resulting in the regression results do not support the hypothesis. Second, in recent years, as the state has issued a series of policies to encourage the financial system reform, China's financial development scale has been developed. Howere,due to capital gains and hedging effect, financial resources in different regions and industries can not be effectively configured, thus making financial development scale can not play an effective role. According to the study by Shi and Wang (2010) [28], Qian et al. (2010) [29]; Lu and Li(2016) [30], the impact of financial development on innovation has a certain threshold effect. The scale of financial development in many parts of China has not yet crossed the higher threshold. Therefore, financial development scale can not to play an effective role in promoting green innovation, and even inhibit corporate green innovation.

As shown in Table 2, it implies that the regression coefficient of government R\&D subsidies is negative but not significant (Coef $=-3.91, \mathrm{p}=0.42$ ).It is assumed that $\mathrm{H} 4$ has not been validated. Analysis of its causes, may have the following points. First, it may be due to government R\&D subsidies has a "crowding out" on enterprise R\&D investment. When the government $R \& D$ subsidy rate is high, it will have crowding-out effect on enterprise $R \& D$ investment, leading to negative impact. Second, moral hazard may occur because of imperfect information disclosure mechanism and capital supervision mechanism. In this case, enterprises may investe government subsidies in activities that are not related to green innovation. Third, the impact of government $R \& D$ subsidies may also be affected by the policy environment and the nature of the enterprise. Enterprise which has close ties with the government and strong policy background would be more likely to achieve the purpose of rent-seeking, while, those which really need government R\&D subsidies for green innovation may not get the government's support. Just as Liu et al. (2012) [31]found, the poorer the regional policy environment and the weaker the anti-corruption, the less the effect of government R\&D subsidies.

\section{Conclusions}

Based on panel data of 2008-2014, this paper studies the impact of financial development scale, financial development structure, financial development efficiency and government $R \& D$ subsidies on the green innovation of 
enterprises in 30 provinces of China. The following conclusions are drawn and the corresponding suggestions are given .

First, the different dimensions of financial development have different effects on green innovation. There is a negative correlation between financial development structure and green innovation, which shows that bank-oriented financial development structure is not conducive to the green innovation activities of enterprises.Financial development structure will be affected by historical conditions, legal environment, culture, politics and other factors. It is hard to say that the financial market-based structure is better or bank intermediaries based financial structure is more advantage. But in terms of promoting enterprise innovation, the direct financing structure dominated by financial markets is more effective. Therefore, in the structure of financing model, China should actively develop financial markets, increase the proportion of direct financing, and build a financial market system that coordinates the development of direct financing and indirect financing.

On the current development situation, China's financial development scale has yet to be expanded. All regions should speed up the development of multi-level capital market, encourage the development and construction of small and medium-sized bank financial institutions, investment financial institutions and financing intermediary services .Encourage private capital to enter the banking industry and build a property rights coordination, mixed all and effective competition in the financial service system. At the same time, the government should regulate the development of Internet finance and build a mainstream format and the new format coordinated development of the financial system to weaken the capital gains and risk. And the government is committed to the effective allocation of financial resources in different regions and different industries.

Financial development efficiency has a significant positive effect on the green innovation of enterprises. Therefore, goverment should pay attention to the continuous improvement of financial development efficiency. Simultaneously, enterprises should actively respond to the call for of the "13th Five-Year" financial system to deepen reform, assimilating the green development concept into the enterprise development process. And continuously improve green innovation capacity, making enterprises more competitive advantage.

Second, in view of the government $R \& D$ subsidies for green innovation is not significant, this paper puts forward three proposals. Firstly, the government should establish an effective supervision and control mechanism and do it well in market research to reduce the asymmetry of information, implementing government R\&D subsidies. Secondly, the government should strengthen the anti-corruption education to the relevant government staff and enterprises, construct the healthy policy environment, standardize the subsidy procedure and make the government R\&D subsidies more standardized and transparent. Thirdly, enterprises should rationally plan their own R\&D investment so as to reduce the negative effects from government R\&D subsidies "crowding out".

\section{References}

1. Acemoglu D, Aghion P, Bursztyn L, et al. The environment and directed technical change. The American Economic Review, 2012, 102(1): 131-166.

2. Levine R. Financial development and economic growth: views and agenda. Journal of economic literature, 1997, 35(2): 688-726.

3. Hall B, Van Reenen J. How effective are fiscal incentives for R\&D? A review of the evidence. Research Policy, 2000, 29(4): 449-469.

4. Hall H, Lerner J. The financing of R\&D and innovation. Handbook of the Economics of Innovation, 2010, 1: 609-639.

5. Ben S, Goaied M. The determinants of commercial bank interest margin and profitability: evidence from Tunisia. Frontiers in Finance and Economics, 2008, 5(1): 106-130.

6. Habib A. Corporate transparency, financial development and the allocation of capital: empirical evidence. Abacus, 2008, 44(1): 1-21. 
7. Sun Wuqin, Wang Wei. Chinese Financial Development and Promotion of Technological Innovation. Management World, 2013 (6): 172-173.

8. Bai Ling, Jiang Lei, Zhan Benfu. Finance Development System, Capacity and Transformation of Technological Innovation Output - An Empirical Study from Provincial Dynamic Panel Data.Comment on the Sankei, 2013 (1): 15-25.

9. Miao Miao, Xiao Hongjun, Zhao Shuang.Research on the Relationship among Financial Development, Technological Innovation and Economic Growth - Based on Panel Data of Provinces and Cities in China.Chinese Journal of Management Science, 2015 (2): 162-169.

10. Guo Guohua, Liu Lintao, Chang Xinxin. Research on the Relationship between Financial Structure and Independent Innovation in China. Technology Economics, 2011 (3): 19-24.

11. Zhang Zhiqiang.Financial Development, R\&D and Regional Technology Deepening . Economic Review, 2012 (3): 82-92.

12. He Guohua, Chang Xinxin.The Characteristics of China's Financial Structure and Its Restrictions on Enterprise Independent Innovation. Wuhan Finance, 2010 (2): 8-11.

13. Roger S, Vlček J. Macroeconomic costs of higher bank capital and liquidity requirements. IMF Working Papers, 2011: 1-51.

14. Ferreira A, Matos P. Universal banks and corporate control: Evidence from the global syndicated loan market. Review of Financial Studies, 2012, 25(9): 2703-2744.

15. Sun Wuqin, Zhu Shunlin.The Efficiency of Financial Development to Promote Technological Innovation: An Analysis Based on Malmuquist Index. Statistical Research, 2008 (3): 46-50.

16. Yager L, Schmidt R. The Advanced Technology Program. American Enterprise Institute, 1997.

17. Brander A, Spencer J. Export subsidies and international market share rivalry. Journal of international Economics, 1985, 18(1): 83-100.

18. Hewitt-Dundas N, Roper S. Output additionality of public support for innovation: evidence for Irish manufacturing plants. European Planning Studies, 2010, 18(1): 107-122.

19. Bai Junhong, Li Jing.Government R \& D Funding and Enterprise Technology Innovation: An Empirical Analysis Based on Efficiency.Financial Research, 2011 (6): 181-193.

20. Ding Kai, Zhu Shunlin.Study on the Impact of Government R \& D Subsidy on Technological Innovation Performance - Based on China's High-tech Industry Perspective. Science and Technology, 2016 (1): 37-41.

21. Li Wanhong, Bi Kexin, Sun Bing. The Impact of Environmental Regulation Intensity on Green Technology Innovation in Pollution-intensive Industries: An Empirical Test Based on Panel Data from 2003 to 2010 .Research and Development Management, 2013 (6):72-81.

22. Wang Fengzheng, Guo Xiaochuan.Effects of Environmental Regulation Intensity on Green Technology Innovation in Resource-based Industries: An Empirical Test Based on Panel Data from 2003 to 2011.China Population, Resources and Environment, 2015 (1): 143-146.

23. Tao Changqi, Ju Zexia.The Empirical Analysis on the Relationship among Financial Development, Environmental Regulation and Technology Innovation - Based on the Panel Threshold Regression Model.Journal of Jiangxi Normal University (Natural Science Edition), 2015 (1): 27-33.

24. Wang Jun. An Empirical Study on the Impact of R \& D Subsidies on R \& D Input and Innovation Output of Enterprises .Research in Science, 2010 (9): 1368-1374.

25. Barro J, Lee W. International data on educational attainment: updates and implications. oxford Economic papers, 2001, 53(3): 541-563. 
26. Ran Guanghe, $\mathrm{Xu}$ Kun, Lu Zhaoyang.Financial Development, the Impact of FDI on Regional Innovation Capacity. Scientific Management, 2013 (7): 45-52.

27. Kang Zhiyong, Zhang Jie.Study on the Influence of Chinese Financial Structure on Independent Innovation Capability. Statistics and Decision, 2008 (19): 130-133.

28. SHI Wenming, WANG Yu-huai.The Threshold Effect of Financial Development on Technological Progress: An Empirical Study Based on Provincial Panel Data.Shanxi University of Finance and Economics, 2010 (9): $38-45$.

29. Qian Shuitu, Zhou Yongtao. Analysis on the Threshold Model of Financial Development, FDI and China's Independent Innovation Capability. South China Finance, 2010 (10): 24-29.

30. Lu Yingfei, Li Zheng. The Threshold Effect of Financial Development on Innovation Efficiency. Journal of Northeast Normal University (Philosophy and Social Sciences), 2016 (5): 75-79.

31. Liu Hong, Xiao Meifeng, TANG Qing-quan. The Incentive and Crowding-out Effects of R \& D Subsidy on Enterprise R \& D Expenditure: An Empirical Analysis Based on Chinese Listed Companies Data.Economic Management, 2012 (4): 19-28. 